\title{
Transformações da agricultura familiar e impactos ambientais. Estudo de caso do reassentamento Santa Bárbara - Cascavel - PR
}

\author{
Inelves DANI
}

Dissertação de Mestrado: Curso de Mestrado em Geografia - UFPR

Data da defesa: 28 abr. 2003

Banca:

Everton Passos (orientador)

Osvaldo Heller da Silva

Ana Maria Muratori

\section{RESUMO}

Esta dissertação, que consiste em um "Estudo de Caso", tem por objetivo identificar o processo de ocupação e uso dos solos e as transformações da paisagem nas últimas quatro décadas no município de Cascavel e nas comunidades estudadas, Foz do Chopim, Santa Catarina e Santo Izidoro, com base no princípio da modernização agrícola, no "binômio" das culturas da soja e trigo/milho para exportação, e na aceleração dos impactos socioambientais. O "estudo de caso" detém-se sobre o reassentamento coletivo que acomodou as 97 famílias de agricultores atingidos pela construção da barragem de Salto Caxias, numa área de 1.087 alqueires, com um projeto alternativo de "Agricultura Familiar" na perspectiva sustentável. A sustentabilidade do projeto no sentido pleno, além do enfoque técnico-produtivo e econômico, não prescinde do enfoque ambiental, base do presente estudo, cuja análise se relaciona com a eqüidade dos meios de produção. O recorte espaço-temporal da ação humana, tanto pela retirada da madeira como pela introdução da modernização agrícola, foi efetivado por meio das fotos aéreas de 1950, 1980 e 1995 e dados da pesquisa de campo. Os resultados da pes- quisa evidenciaram que com o projeto houve uma recuperação gradativa das matas ciliares e do solo, e que também vem ocorrendo uma redução, ainda que incipiente, do uso de agrotóxico, com o cultivo de produtos orgânicos. Constituem ainda aspectos a serem superados a insuficiência alimentar e a dependência química do meio de produção. Entre os aspectos positivos destacam-se a preservação dos laços familiares com o novo lugar e o fato de este projeto não ser algo acabado, imposto, mas discutido pelas lideranças dos agricultores, estimulando uma dinâmica de troca de experiências entre as comunidades e os coordenadores. $\mathrm{O}$ modelo estudado demonstra que é possível a superação da dicotomia entre "agricultura familiar" e "modernização agrícola" mediante efetivação de políticas públicas para os segmentos menos capitalizados do campo.

\section{Palavras-chave:}

Reassentamentos coletivos, agricultura familiar, sustentabilidade, transformação agrícola, impactos socioambientais, produção agrícola, conservação, dinâmica da paisagem rural. 